\title{
PEK盗TA
}

\section{THE REASONS OF HOMESCHOOLING IN THE SZEKLER REGION, ROMANIA}

\author{
Kinga Magdolna Mandel
}

\section{Motto "everyone teaches at home, only some even send their child to school" (citation from homeschooling parent)}

\begin{abstract}
The aim of this paper is to analyze the reasons for homeschooling in the Szekler region in Romania. While doing so we are comparing our research results with the Anglo-Saxon and mainly American literature regarding the reasons for homeschooling. Based on a social constructivist (Vygotsky, 1986) and stakeholder (Smith, 2000) methodological framework, we developed a qualitative research inquiry, with semi-structured, theme-centered interviews, processed in Excel. The conclusion is that although the main reasons for homeschooling collide with that of homeschoolers elsewhere in the world (mainly the USA), some contextual specificities are locally overwriting some of them. We hope that, our study will assist parents to take a wiser decision on whether to choose this schooling option or not, but also schools and decision makers involved in education to assess their roles in the process and make changes if they consider so.
\end{abstract}

Keywords: Homeschooling, Szekler region, Romania

\section{Introduction}

According to the definition, homeschooling is a parent-led home-based education, sometimes also called home-education (Mandel, 2020 citing Ray 2017). The terms home schooling, unschooling, home-based education, education otherwise, domestic education, home based education and home education are also used for homeschooling. People in everyday life sometimes confuse the homeschooling with private education or extracurricular private classes. The difference stands in the teacher's role: that in homeschooling the parents are performing the task of the teacher with or without a pedagogical background, while in private education professional teachers are providing teaching, offering their services for money. Similarly, in the case of private classes (tutoring), professional teachers are giving those classes in addition to that offered by the schools. In the case of homeschooling the children are not attending the school daily, they are just participating in examinations held at state owned schools or school centers at the end of semester or year. However, many times homeschooled students are also taking private classes, in different subject and/or areas like music, sports or other subjects (for example math) that their parents are not mastering, or they better ask for professional assistance. The homeschooling is sometimes confused with unschooling. The difference is in approaching the process of learning. In a homeschooling, parents act like teachers in the classroom. Unschooling is based on the children's natural curiosity and follows its interests in their own way (Mandel, 2020 citing Miller, 2014) sometimes using the natural intergenerational learning possibilities (Simándi, 2018). In this study, we focus only on homeschooling.

Homeschooling families could teach in many ways. The most common methods are: "unschooling," "classical education," "Charlotte Mason method," "traditional school-at-home", "cooperative schooling" and "computer-based home education" (Eggendorfer, 2016 citing Taylor- 
Hugh, 2010). Methods often vary in each family, parents and children mixing the elements they like. Some of them teach at home based on the principles of Maria Montessori and Rudolf Steiner (see Montessori Homeschooling and Waldorf Homeschooling websites). In most of the methods listed so far, the basic element is to encourage children to act independently (Eggendorfer, 2016).

\section{Reasoning}

Simon Sinek (2009) said that to be motivated we always must start with the why and we have to ask at least three times in order to get the best, the inner answer to it. This study is dedicated to find out the why of homeschooling in Szekler region.

Studying homeschooling is important, because already in 2001 the OECD Secretariat report on the future of education portrayed in its fifth Scenario, the future school, as a school without a school, meaning that the role of the schools would be taken by student networks. In the description of this scenario, special attention was given to the continued expansion of home education. (Mandel, 2020 citing OECD, 2001, 93.) The educational situation developed because of the COVID 2019 pandemic took this scenario even closer to us, when almost every pupil and parent get some insight in how homeschooling could work.

In 2007, an estimated 1.5 million children in the United States were being homeschooled (TaylorHough, 2010). In 2016, there were over 2.3 million homeschooled students (Mandel, 2020 citing Ray, 2015). This development shows that in 9 years the number of homeschooled increased significantly, almost doubled. Homeschooling there a decade ago appeared to be cutting-edge and "alternative" but is now bordering on "mainstream". Home-based education has also been growing around the world in many other countries (e.g., Australia, Canada, France, Hungary, Japan, Kenya, Russia, Mexico, South Korea, Thailand, and the United Kingdom) (Mandel, 2020 citing Ray, 2015).

The phenomenon spread in Central and Eastern European (CEE) countries as well, Romania being amongst them. Based on the 2015 data of the Association of Homeschooling Romania, more than 300 families were involved in Romania, amongst them at least 30 being Hungarian families (AHSR, 2020). In the present study, we focused on those homeschooling families that are living or originating from the Szekler region, also called Szeklerland by many. Szeklerland is the area of historical Szekler chairs located in the territory of Transylvania. According to scientists, the historical Szeklerland included the present-day Covasna and Harghita counties, a part of Mureş county and smaller pieces of today's Alba and Cluj counties (Bottoni, 2008). In the present survey, we focused on Harghita, Covasna and Maros counties, that are considered by the locals to be part of Szekler region nowadays.

During our previous studies on the Hungarian education in Romania (Mandel 2007, Mandel 2016), we encountered the homeschooling phenomenon to be spreading in the Szekler region in Romania, among Hungarian families as well. This made us curious to detect the reasons of home-schooling (Mandel, 2020).

The European Free Education Forum supports the homeschooling (Mandel, 2020 citing AHSR, 2019). However, there is no private student status in the Romanian education system; only children with disabilities have the right to study at home. Still, a home-educated student could be registered at a foreign country's educational institution (usually in Hungary and USA) and the diploma issued by those institutions is accredited in Romania. There are also schools in Romania that have applied for accreditation from accreditation agencies in the USA or Great Britain, thus gaining the right to offer the Baccalaureate Diploma for children enrolled in the homeschooling system. However, the most accessible and easy way, both materially and academically, is to enroll in a regionally accredited school (to have accreditation from one of the US regional accreditation agencies that also make up the AdvancED group and the COGNIA organization) or not accredited from the USA (Curcubet et all, 2020).

\section{Research question and hypothesis}

What are the causes of homeschooling in the Szekler-region? We assumed that besides of the general ones, like the dissatisfaction with the quality of the mainstream education, the lack of private and 
alternative education offers in the educational market, the conviction that one could educate better its own kids, than the teachers do and so on, we would also find some specific reasons for homeschooling in Szeklerland, than those widespread in the world. More exactly in the case of Hungarian children in this region, we assumed that one of the main reasons could be the systematic disadvantage of Hungarian students in state language exams (Romanian) and the pursuit to somehow avoid it.

\section{Research methods}

The theoretical framework for our research is offered by the social constructivism and that of stakeholder analysis. The social construct theory considers that human development is socially situated, and knowledge is constructed through interaction with others (Vygotsky, 1986). The stakeholder analysis refers to the range of techniques or tools to identify and understand the needs and expectations of major interests inside and outside of a project or organization (Smith, 2000).

Based on this framework, we realized individual and group interviews with homeschoolers above 18 years and their parents, using snowball method of sampling, starting with the presidents of the Association of Homeschooling Romanian and its members. We had this specific target group because we were also curious of the long-term outcomes of the homeschooling (for example the transition into higher education and job market), topic which would be discussed in a further publication.

Ten semi-structured 45-60 minutes topic-focused interviews were realized, because of the virus situation, through the phone and internet, using different video or voice call applications like the Skype and Messenger. Seven individual and three paired interviews were carried out, where we talked with couples (husband and wife), thus fourteen people were included in this sample. Nine parents (out of which two pairs) and four youngsters (out of which one pair) answered our questions. The seven families included in this research were raising and homeschooling 25 children, meaning an average of $3,57 \mathrm{kid} /$ family, the least being 2 and the most 6 children. Based on our sample we could state that similarly with the results of the NEHRI's (National Home Education Research Institute) results on American homeschooling (Ray, 2019), the homeschooling families are larger than the average in Szeklerland as well.

We had interviewees from Székelyudvarhely (Odorhei) - Harghita county, Sepsiszentgyörgy (SfantuGheorghe), Zalán (valea Zalanului), Barót (Baraolt) - Covasna county, and Szováta (Sovata) - Mures county. We did not cover the Gyergyószentmiklós (Gheorgheni) region, because the families there started homeschooling later, thus they have no children above 18 years. We did a sequential interview with the head of the AHSR, as we talked with him in two different time, first in 2019 in the orientation phase of the project and for the second time in 2020. Some of the families and their youngsters already left Szeklerland (at least temporarily), thus we had interviewees in Kolozsvár (Cluj-Napoca) - Cluj county, Nagyvárad (Oradea) - Bihor county, Miskolc (Hungary), Wien (Austria) and we even reached one family in a refugee camp in Iraq. In the analyses we also used three previous conference presentations held in 2015 and a couple of papers issued by the homeschoolers.

\section{Reasons for homeschooling}

Jane Van Galen (1991) differentiated two reasons for homeschooling, one ideological and the other one pedagogical. The ideological category includes parents who, for religious reasons, do not send their children to school, they are mostly politically conservative, and Christian. The main goal of "ideologues" is to be able to convey to their children their views, values and worldviews related to their religion within the framework of home education. The pedagogical category includes parents who are dissatisfied with public education or even with the whole school system, its methods and effectiveness (Eggendorfer, 2016 citing Taylor-Hugh, 2010). We also found these two basic elements in between the reasons for homeschooling in Szeklerland, with a slight overweight of the ideological elements, that were present in all families included.

Ed Collom (2005) found that we need to further distinguish at least four categories of homeschooling reasons, which are: (1) ideological, (2) pedagogical, (3) general dissatisfaction with public education, (4) family-related reasons such as health care or special educational needs. Nowadays, an increasing number of families choose home education because of its academic success (Eggendorfer 2016 citing 
Taylor-Hugh, 2010). David Carlson pointed out that home teaching can also be an excellent method of bilingual education (Eggendorfer, 2016 citing Carlson, 2009)

According to the National Household Education Surveys Program (2016) in the USA, the highest percentage of homeschooled students had parents who said that a concern about the environment of other schools, such as safety, drugs, or negative peer pressure was a reason to homeschool ( 80 percent) and the desire to provide moral $(67 \%)$ and religious $(51 \%)$ instruction. $61 \%$ of the respondents was dissatisfied with the academic instruction at other schools. Other reasons included to provide a nontraditional approach to child education and different special needs of the child, such as physical, mental problem and temporary illnesses.

Table 1. Percentage of school-age homeschooled children, ages 5-17 with a grade eqivalent of kindergarten through grade 12, by reasonons parents gave as important and most important for homeschooling: 2015-16, United States (Source: NHES, 2016)

\begin{tabular}{|l|l|l|}
\hline $\begin{array}{l}\text { A desire to provide religious } \\
\text { instruction }\end{array}$ & Important & Most important \\
\hline $\begin{array}{l}\text { A desire to provide moral } \\
\text { instruction }\end{array}$ & 67 & 16 \\
\hline $\begin{array}{l}\text { A concern about environment of } \\
\text { other schools }\end{array}$ & 80 & 5 \\
\hline $\begin{array}{l}\text { A dissatisfaction with academic } \\
\text { instruction at other schools }\end{array}$ & 61 & 17 \\
\hline $\begin{array}{l}\text { A desire to provide a non- } \\
\text { traditional approach to child's } \\
\text { education }\end{array}$ & 39 & 6 \\
\hline Child has other special needs & 20 & 6 \\
\hline $\begin{array}{l}\text { Child has a physical or mental } \\
\text { health problem }\end{array}$ & 14 & 6 \\
\hline Child has a temporary problem & 4 & - \\
\hline Other reasons & 22 & 11 \\
\hline
\end{tabular}

Similarly, according to the president of the Association for Homeschooling Romania, Gabriel Curcubet, the reasons for homeschooling include the following:

- the crisis in the public education system, this can be academic, moral and philosophical;

increased dissatisfaction among parents with teaching methods, and insufficient training of teachers

- the desire to use a more efficient teaching methods;

- the child's disease that does not allow her/him to go to school or he/she is simply more active then her/his peers;

- $\quad$ the children needs more specific teaching materials (Curcubet et alii, 2020).

\subsection{Ideological reasons for homeschooling}

Montes (2006) found that parents homeschooled mainly for religious reasons (41\%). Similarly, other American researchers started with the hypothesis that the homeschoolers have a religious conviction as a reason for homeschooling, which turned not to be fully adequate. According to the literature, a wide variety of people homeschool - Atheists, Christians, and Mormons; Conservatives, Libertarians, and Liberals (Mandel, 2020 citing Ray, 2019 citing Noel, Stark, \& Redford, 2013). However, later some of the authors stated that $77 \%$ of the people homeschool because of "a desire to provide moral instruction" and 64\% of "a desire to provide religious instruction" (Mandel, 2020 citing Redford et al, 2017). It seems that the number of parents that are homeschooling because of the religious reasons increased over time, from 41\% measured by Montes in 2006 to 77\% stated by Redford et alii in 2017. 
We have found that most of the Szekler homeschoolers, even families called by the others to be "hippie homeschoolers", referred to the Bible, stressing the parents' responsibility in the education of their kids, as a reason for homeschooling, eg.:

"I am convinced that as a parent I am the number one responsible for my children" (Szász, homeschooling parent, 2020)

Most of the families included in this research homeschool to teach their kids the basic Christian values, assuring thus a moral instruction with a religious background.

"In any case, the Christian parent wants to teach at home in a Christian way. Now in a Christian way to teach at home means, you don't want to have everything, now you don't put your child under a hood. He still encounters sin anyway, the parent does so many things to learn it, but he's already in his heart, so no, it's not hard to do that. But, it really means a lot of uselessness, that school can do and a lot of time this is more of a problem. So the Christian parent says why fill my child's head with things I don't agree with, if they can be taught in a Christian way about normal things (Curcubet G. interview, 2019).

The very first families of the homeschoolers in Romania started to homeschool in 2001-2002, following the American homeschooling model. They got "infected" with the idea of homeschooling, by receiving a video tape about homeschooling in a family reunion in 2000, a conference organized for the big families. At first, they resisted the idea, however in the next couple of years, in 2001 and 2002 they also met an American homeschooling pair, in a similar event, and learnt more about homeschooling. In the next couple of years, three families started to homeschool. Those pioneering families were belonging to the same reformed Presbyterian community, supporting each other with information. Later, in 2003-2004 other families, joined. Only around 2015-2016 became more widespread to home school. Interestingly, a media campaign on Antena 3 TV station assisted in this late development. The show had the hidden aim to blacken homeschooling. Instead, it contributed to its further spread countrywide. It is difficult to assess how many people homeschool in the present (2020) in Romania or in the Szekler region, because people are afraid of the possible negative consequences, so there are no records of homeschooling families, just estimations. According to the president of the Association of Homeschooling Romania, there are between 3600-5000 families in Romania that are homeschooling, around 100 of those being families belonging to the Hungarian minority culture (Curcubet G. interview, 2019; Curcubet et alii, 2020). Those numbers are 10 times more than previously stated in 2015 .

\subsection{Living cultural differences though homeschooling}

According to the north-American literature $40 \%$ of parents with African-American origin were choosing homeschooling in order to "give the child more instruction on African American/black culture and history" and 20\% named the "desire to avoid racism in public schools" (Mandel 2020, citing Ray's 2015).

Homeschooling for the maintenance of cultural diversity, in our case that of Hungarian language and culture in a Romanian context, could be considered to be an ideological and pedagogical reason for homeschooling, linking the two main reasons. It is ideological as through the language (being a minority language) worldview and values are transmitted, pedagogical as the parents probably are not fully satisfied with the mainstream education regarding the minority culture or dominant language transmission.

Our hypotheses stating that the Szekler parents belonging to the Hungarian minority are probably homeschooling to prevent their children from the failures at the Romanian national tests at the end of the 8th and 12th grades, proved not to be reliable, as no one of the parents accentuated this aspect. Only the president of the Association of Homeschooling Romania admitted that homeschooling could be a solution for minority children and their parents to overlap the Romanian language state exams and get a valid baccalaureate, although the parents usually are not opting for it because of this reason (Curcubet, 2019). 
"Not really, the Romanian language, so almost everyone somehow feels that I should learn this, it is good, it is useful... if someone goes somewhere in Brasov, the Romanian language should already be useful, there is nothing wrong with it... but getting rid of the Romanian education system that is it... Cosbuc, Sadoveanu and I don't know what they are asking for, which you will never need in life and in a language ... if you have learned to read Sadovanu nicely, still, you have no idea what the other Romanian is talking about" (Curcubet, 2020).

\subsection{The pedagogical reasons for homeschooling}

The pedagogical reasons may be split into many sub-elements, like the fear from negative socialization and the dissatisfaction with the quality of education.

\subsubsection{Negative elements of school socialization (safety, drugs, mobbing, racism, violence)}

In the USA, most parents (91\%) named „safety, drugs, or negative peer pressure” at schools as causes for homeschooling (Mandel, 2020 citing Redford et al, 2017). Fields-Smith and Kisura (2013) reported that parents opted for it, because "homeschooling also allowed them to 'slow down' their children's exposure to what could be deemed as unsavory elements of school socialization (e.g., racism, violence, drugs, etc.)."

Parents opt for homeschooling to provide guided and reasoned social interactions with youthful peers and adults. To provide a safer environment for children and youth, because of physical violence, drugs and alcohol, psychological abuse, racism, and improper and unhealthy sexuality associated with institutional schools, and teach and impart a particular set of values, beliefs, and worldview to children and youth (Mandel 2020 citing Ray, 2019).

These causes were mentioned in our interviews with Szekler homeschooler's as well.

"Home education can protect the child from influences for which he or she is not prepared" (Szász, homeschooling parent, 2020)

"The seedling is not planted in the frost yet, only a little later, when there is no big frost or it can withstand" (Simon, homeschooling parent, 2020)

Protection and preparation for life in a safe environment are the two pillars in which the Szekler homeschoolers based their argumentation in a positive manner.

Some of the parents mentioned to know families that took out their kids from the mainstream school because of the unbearable stress caused by the school environment.

"Then another mom (said), their child had stomachache on Sundays, he was ruined because school started on Monday. So, there were a lot of negative effects of the school, that a child was sick with them. We know someone, who had stitches, a girl that had all sorts of grimaces during the school period, after that she was taken out of school, recovered" (Simon homeschooling parent, 2020).

"Well, they take it out (from school) because it raises a problem with their child, anxiety or anything that makes the school so negative" (Kovácsné homeschooling parent, 2020)

Among the negative school socialization elements, we could think of the public humiliation, or the fear from it.

"A home-educated child is not exposed to public humiliation to the same extent as community education, making it easier to take the risk of individual attempts" (Szász notes, 2015).

The home education serves as shelter for those students that are below the average from some aspect, because they are slower, or they can grasp the correlations slower, or just cannot stand in one place for a long while.

"Home education is for all children who are afflicted, tormented and lost in the sink of public education" (Király, homeschooling parent, 2020). 
"We have seen many positive healing examples of socialization, in the case of those who were already in the system and came out" (Simon, homeschooling parent, 2020)

Although we supposed that drugs are not a problem yet encountered in this region, the facts are showing, that the American reality, shown in news is ours as well.

"The superintendent spoke in horror that her 3-year-old child would soon be included in the (education) system and she was already dreading in advance what would happen. Because she worked right at the department where she ran into cases like this, like taking drugs, that fainted half of the class and then there was a big circus, got out the police, investigated the case and she had to lead this while her child was there too, going to school soon" (Szász, 2015).

The sexual education is also a topic taught differently in Christian conservative families than in the mainstream schools, where a postmodern approach seems to get priority.

"I've heard stories from schools lately that I couldn't have put together such scenarios with the most pessimistic idea, so maybe I can give a few examples during the conversation, so it's scary what direction things are going. On an unofficial site, I don't know who knows the program prepared for sex education, which is on the internet. For the time being, such a pilot project is running, there are some schools in every county that are also registered here, some teachers are trained, the goal is to then have such teachers in every school.... so it's worth looking what they're trying to prepare these kids for" (Szász, 2015).

Next to the protection from negative socialization elements, there is also an opposition to the mainstream education system, the values and ideologies lying behind it.

"Well, for that child's money, we won't sell our child to the state every month, but we want to raise our child ourselves" (Curcubet homeschooling parent, 2020).

"The goal of homeschooling is not to permanently isolate a child from this world, but to prepare him or her for how to face these dangers, not to give it to this system but shape into his/her own image and likeness" (Szász, homeschooling parent, 2020).

There is also a rejection of the widespread contra-argument against homeschooling, the isolation of the child, the lack of socialization with peers, as there is the assumption of the full parental roles, to shape the children according its own parental image and likeness.

“... Many people think that it is a state of unconsciousness that the child is learning from you. Maybe it will impose certain values, would contribute to admire his parents, or look up to them. This concept is no longer valid today and then.... many parents are bitter because their kid put up a photo of someone holding their hair that way or with an unimaginable color... well now that's what she/he found, she/he was thrown out into this environment to look for something (role model, example) for himself and then she/he searched and found..." (Szász, 2015).

\subsubsection{Character formulation and value transfer through homeschooling}

The value transfer is at the base of the character formulation and gives the moral or religion background of homeschooling in Szeklerland.

"Public education even at the academic level, fails quite a bit in the field of character education, in the field of transfer of values, I think it is completely helpless, or almost completely helpless" (Szász, homeschooling parent, 2020) furthermore the parent considers that "The framework of homeschooling is much better in the matter of character formation and the transfer of values" (Szász, 2015).

Homeschooling could assist in overpassing learning, psychological and physical problems which was a valid and important problem in the case of $38 \%$ of American parents as well in 2016 (NHES, 2016).

"I would definitely recommend it to someone, for whom is important shaping the character of their child, and for those who may now have learning difficulties, or some physical problem, even children who, for some reason are not accepted into the community, find it difficult to integrate" (Király, homeschooling parent, 2020). 
We could pose the question how will solve the kid's integration problem if we take her/him out of school. Homeschooling parents argue that if the kids are taught in a secure environment, at home, without disturbing socializing elements, judging classmates and teachers, they could focus more on the inside, get to learn more about themselves, which give them self-confidence needed to be able to connect with others.

"It clearly strengthens their personality so that they study at home. There aren't that many compliance compulsions, meeting peers, meeting teachers, meeting everything... and it is in this compliance compulsion in that you lose yourself, to know who you are, your strengths, weaknesses, and to work on yourself" (Király, homeschooling parent, 2020).

It was astonishing, how homeschooled children reacted to the mainstream school environment after several years of homeschooling, by refusing their peers' behavior as being meaningless.

"we took them to school several times, then their reaction was, that the lessons were interesting, but that the rage, the screaming, the rush had taken place in the break it shocked them because they saw no rationality in it. So, what's the point of yelling, running, jerking the other one there, so it shocked them because it's not something within their worldview... So, the fact that there are a lot of kids is interesting for every kid, if there are a lot of kids but that... They jerked, yelled, fluttered, fought, so they watched them in shock..." (Szász, homeschooling parent, interview, 2020).

Homeschooling in terms of social integration or cohesion could also provide a much more advantageous background by bridging the generational gaps.

"What is increasingly observed today is that there is a growing gap between different generations. We really see that there is a growing gap between parent-child, sometimes, there is a distance between siblings, or between grandchildren and grandparents, not to mention how they relate to older people who are not in the family. Now there is very little to wonder when someone grows up being isolated from all other ages, only closed with their peers (Szász, 2015).

According to our interviews, homeschooling helps not only to communicate with the elders but strengthens the relations in the family among brothers and sisters:

"And then the kids are much closer to each other too, helping each other and being real good friends. It's not like I see it in other kids, they quarrel with their brother because he has a girlfriend and a boyfriend, from school, he's close, he's not from school but with his brother, and here he's close with his brother, very strong very tight" (Gergely, homeschooling parent, 2020).

Homeschooled children learn to support kids belonging to younger age groups, which is quite rare in a usual school setting, where it is not considered to be cool to have smaller friends, even smaller brothers, and sisters.

"Now it has such practical manifestations of how different the socialization of our children was...I remember a camp where, there was a family camp and there were parents, children, children of all ages, and these home-educated children so naturally without anyone would have told them, they started organizing different programs for the little ones. And then, after a while, a puppet theater was organized for them, and after a while, even during meals, everyone slowly developed to have such a protégé and then, for the weekend really, so every older child had a protégé of a smaller child, but it developed naturally. For example, my 17-year-old son fed a 3-year-old girl all week and was with her all the time" (Szász, 2015).

\subsubsection{Quality of education as a reason for homeschooling}

Montes (2006) found that homeschooler parents believed that they could provide their kids better education (47\%). "A dissatisfaction with academic instruction at other schools" (74\%) was the second most important reason for homeschooling later as well (Mandel, 2020 citing Redford et al, 2017). In our previous studies (Mandel \& Papp, 2007) on the quality of the higher secondary education schools having Hungarian as teaching language in Romania we also encountered high dissatisfaction with the quality of education among all stakeholders involved; managers, teachers, students, and parents. 
Based on the literature rents opt for homeschooling to customize or individualize the curriculum and learning environment for each child, to accomplish more academically than in schools, to use pedagogical approaches other than those typical in institutional schools, to enhance family relationships between children and parents and among siblings (Mandel, 2020 citing Ray, 2019).

Those are the benefits of homeschooling according to our interviewed parents as well: the personalized attention and occupation with the kids, the curriculum tailored to their needs and capacities, the lack of other disturbing elements in class, an independence in thinking, studying and research reached at an early age.

"Self-determination and individual thinking [are the outcomes], that he or she does not have an opinion of something determined by others that has been told to him, but examines a thing from several aspects, how it could be done" (Blaga, homeschooling parents, 2020).

One main reason for homeschooling mentioned by the parents is that it provides a personalized, differentiated education.

"Every child has the endowments with which God has gifted him, which, if we find a place where he can take advantage of it, every single child is valuable, but within a system that uniforms, those who would outperform are cut back and those who would not move so fast are forced to speed up" (Szász, 2015).

Homeschooling is tailored to the personal needs, abilities, capacities, and speed of the kids according more freedom and independence in thinking, learning and research.

"Homeschooling provides an individual occupation with the student, which is in community education is possible in a limited way... is much more effective as it provides direct communication between teacher and student and an opportunity to tailor the curriculum keeping in mind the student's abilities. In home education, the child progresses with the material depending on his or her own capacities and abilities. Homeschooled children grow up on independence much sooner, they start much earlier curriculum-related individual research than their peers in community education. Taking it into account individual abilities makes it possible to stimulate individual thinking and research." (Szász notes, AHSR).

In mainstream school environment there is a levelling to the middle, the teachers are trying to develop the kids in areas where there are not as good as the average by tutoring, thus killing creativity (Robinson, 2014). Whereas in homeschooling there is a flexibility in learning, emphasizing on the kid's personal interest and parents are developing the kid making even better in areas where it is gifted, fostering creativity.

"There is a kind of flexibility that allows you to use your hobbies or personal interests much better, you can provide more time for, say, elite athletes, or those who play music or do something at a higher level, it is much more an opportunity to practice this interest" (Szász, 2015).

According to the parents, homeschooling is more effective and real in the evaluation of the kids' performance, which is another feature to consider.

„What hurt me so much is the amount of time, we spent tormented... when the 7-8 year old child was all day, after about 4-5-6 hours spent in school, coming home and studying hard in the evening and the result and the progress was not what the work, the time invested was, at all... We had problems with his evaluation, then he started to be very, very anxious, producing symptoms like his hands were sweating terribly, so much so, that we had to put such a small towel... wipes that soaked the sweat from his hands, so he didn't soak his notebook. And we went crying, we came crying." (Kiraly, homeschooling parent, 2020).

As we have already mentioned, the Szekler homeschoolers are matriculated in American or Hungarian schools. In this regard, the American schools are trusting and relaying more on the parent's judgement by leaving the whole evaluation to them. In Hungary in mainstream schools, teachers are regularly examining the performance of the homeschooled children, parents have no right to accord grades, although homeschooling parents say, that 
"it is more efficient and realistic to hold an account, if the parent evaluates his or her own child in person” (Szász, 2015).

Furthermore, as the parent is dedicating more time to the kid, is aware of its strengths and weaknesses, thus could orientate further which direction to follow with the studies and what profession to choose, so it keeps a decisive role in the career orientation of its own child.

"I know what will become of them, that's why it's good to be at home so that we can see better what it has to offer and how we can help develop this part" (Gergely, 2020).

Compared with the mainstream education, homeschooling learning is more efficient, there is less waste of time, so there remains more time for playing and experiencing new things.

"We were surprised at how little time, how much can be achieved without overloading the child" (Szász, 2015).

One would think that the home environment is distracting (this was similarly one reason against the home-office before the spread of Covid19), however it turned out that the school environment is even more so and the kids could do more in less time by studying home.

"In community education, in an average class, the teacher is with one single student ideally only up to 2-3 minutes. In contrast, in home education, as you are the supervising teacher, the student can enjoy the full personal attention of the assisting parent. In this way, even 2 to 3 hours is much larger, they can show progress as participants in community education in 6 to 7 hours..." (Szász notes, HASR).

In the United States the research statistically showed that one in every four children educated at home (more precisely $24.5 \%$ ) is already studying in a class at least one step ahead than his age group (Szász notes, 2015). This phenomenon was mentioned in our cases as well; homeschooled children advanced faster in different subjects (like mathematics) and fields (English, music). Although parents were afraid no to lag behind with the material, the advancement of their kids, usually this fear got swept away by the teachers' regular evaluation where they applauded the homeschooled kids' performance and behavior (Szász, 2020; Király, 2020; Kovacsné, 2020).

"The teachers talked us, to homeschooling parents who were there and said "congratulations because you have such children", when we arrive we bring the maximum, our children fit in perfectly, immediately, without any problems, into the class community, teachers, peers, fantastically well, they are full of positive energy and this is passed on to them as well" (Király, homeschooling parent, 2020).

\subsection{Homeschooling lifestyle}

Studies also stress that homeschooling leads to a lifestyle change, causing less time devoted to learning (where learning is not only happening at home, but in the shop, museum, cultural and other events) and more on playing, better results achieved, better, happier childhood, with less stress, more creativity, more personal fulfillment and new postmodern life-style (https://www.calverteducation.com/should-i-homeschool/homeschooling-pros-and-cons).

Homeschooling is providing a real environment instead of an artificial one

"they grow up in a much more real world" (Szász, 2015);

"more practical, this is discovered in home-educated people, because, for example, we were taught not only to understand the subjects, but to say, we girls could make a lunch, or we did a lot of garden work, cleaning, cooking jam (Blaga homeschooled young women, 2020)”.

There are countries where the mainstream schools are following a homeschooling model or at least taking, copying, and applying some of its elements.

"In Sweden now there is such an attempt to create a complete home environment for the children, the school is furnished as if they were at home, there are sofas, and there are chairs, so it is as if their children were at home, but it is a school. Then, another thing I see is that more and more Western schools are trying to do things to kids that they would otherwise at home. Someone told me, that the kids learn something and then the kids cook together. Then, the kids sew together and then they try to 
do things they are going to do in life anyway further. Well, they realized that they were so torn away from real life by the plastic environment that they would never thrive in so many areas afterwards" (Szász, 2015).

Homeschooling offers the possibility to learn and live in the same time, experience things neither at school, nor at home, but outside in the real world

"Then, due to the flexibility of home teaching, it can take time for a lot of things that you don't. Now they had such an open day, an open day for firefighters. Then we said we're not learning today, we're going to go and see the firefighters on open days, or if it was a night of museums then we went through each museum one by one (Szász, 2015).

As opposed to the mainstream education homeschooling is natural and practical.

"That is how man learns life; life itself is what children learn. After all, learning for us is $50 \%$ theory then at least $50 \%$ practice. So, for them to start life, small, but here under our wings, because it will be much better for them later. They do not teach this life at school, almost anything, very little, so they must get used to what they are going to do every day when they grow up and leave this house. Right, then they have to work, then there will be responsibilities to communicate with younger children, people, so these are essential things and maybe they should be taught as much as the 1789 date in history" (Gergely, homeschooling parent, 2020).

Finally, we should talk about the economic reason for homeschooling because according to most of the parents, homeschooling is cheaper than the mainstream education. They are using the libraries instead of buying books, they are also helping and sharing the schoolbooks and materials and they do not need to follow the fashion regarding the wearing of their kids as the peer pressure forces. However, they spend more on buying museum tickets and on travels to the school examinations, which they also solve by traveling together, sharing cars and the expenses with other families.

\section{Reasons against homeschooling}

The literature and my interviewees also stated that although there are no disadvantages of homeschooling if it is well done, certain conditions must be met, to work.

"I consider it a difficulty, quite a difficulty to change, depends on how old the children is... So, it was very good, that we did this from the beginning, we didn't have to get used to one kind of system, one kind of habit then to another. Moreover, there are those, who already started with a third child and tried, but let us say the first two were already in school and then there was such a double life, that they just couldn't physically coordinate like that. The schoolchildren needed help, to help them to progress, the home-taught has always been in the back, so there was such a ...one or two years of such torment, but no... could not do so" (Kovácsné, homeschooling parent, 2020).

According to the interviewees homeschooling is not for everyone, it needs commitment and dedication.

"What is important is the dedication" (Blaga homeschooling parent, 2020).

„In 16 years, we got to know a lot of people who wanted to teach at home, some who started, then danced back and can almost always be traced back to that one point. That whoever refuses to accept that this is a mission for him, or that he will live it this way, will be very, very difficult, because he will always look at where I can save some time out of it. (Gergely, homeschooling parent, 2020)

Usually parents who have freelancer professions or who could manage that at least one parent stays at home are doing it. In the case of many, above three children, it is cheaper and more reasonable that the mom stays at home educating kids, than working and then paying her wage for a stranger that looks after the kids.

„Both parents, if it is needed, to be able, to help, have such a strong foundation at home that you can really build on, because that I think it's like when they start, you have to hold on to it so that... don't be that, we take it back, then we get it out again, then we get it back again ... I also had such acquaintances who were approx. annually changing from private student to a non-private student.... In 
addition, I think it is necessary to have such a purposefulness, and perseverance on the part of the child that he wants to do it (Simon, homeschooled young lady, 2020).

As we can see above this "job" also needs dedication, commitment not only from the parents but the kid as well.

"There needs to be a kind of consensus in the family about this because either party doesn't really want to do it, then I don't think it's sustainable" (Curcubet, homeschooled young men, 2020).

Although there are good reasons for it, there are also factors that do not drive to successful home schooling. Those reasons include trying something new, or otherwise said let flow by the fashion, the aim to differ from others, the rejection of conventional education and the goal to raise successful child or to prevent the kids to get the current sickness (Covid19).

"Well, I might say that if someone thinks that learning at home, first, you have to account for it in yourself. You have to see clearly whether it is his goal, he wants it, or just because... if it is just a side goal and it says no in him, his heart, only wants to accomplish something secondary, it will not go in the long run. I would add that you should not start because of this (Gergely, homeschooling parent, 2020).

Homeschooling could be damaging if there is no discipline, consistency, flexibility and organization in the family, if there is no good relationship in between the parents, if they are not good role models, if they don't have time for their kids, if they are homeschooling because of egoistic reasons and so on (Curcubet G, 2015, Curcubet G. interview 2020).

"You need to have commitment; you need to have a conviction for what you are doing it and it is very necessary for a person to persevere all the way through... And on some level to believe that we are not going to ruin their lives" (Kovácsné, homeschooling parent, 2020).

Another difficulty is the self-organization, self-discipline of the parent, his/her consistency and perseverance. It is quite requesting to

"consistently keep the program well (Blaga, homeschooling parent, 2020).

A well-known reason against homeschooling is the lack of institutional socialization. The literature mentions as a problem of the home-schooled, that they could be timid and not relate adequately with their peers.

"Disadvantage of.... in my case, they were maybe a bit, that I wasn't in a community because I'm introverted anyway and so that didn't help me. But that I am not saying that everyone who studies at home is like that, but if a person is already introvert, it is not that easy to be in company. When you are in big company every day, then eventually she/he gets there to talk to his mates as well. Nevertheless, when you do not have the opportunity to do that, either you must retreat very much, or you are afraid to capture the moments when it is available. I do not know.... I think I lived both, but I can say that by now it has developed enough in me not to wait for tomorrow about it, but now here and then...(Blaga, homeschooled young lady, 2020)".

The lack of peers could be felt more when a kid is changing from a mainstream school to a homeschooled status, however, this cures with time and we could argue that we lose friends anyway because of character developments that take different paths.

"B: So it was hard to leave the team, I remember, but.... it wasn't particularly... I mean my classmates...Well, at first, it was a little hard to get into learning, and all, but I remember there was no problem.

Q: And then with your classmates, how could you keep in touch? Did you keep it? Have you tried?

B: well, there were people, who did for a while, over the phone, we usually met for a while, and then unfortunately these meetings decreased with time...

Q: And why is that? 
B: I do not know, I think we all changed and since we weren't together, not in one direction (Blaga young lady, 2020).

It seems that the lack of institutional socialization possibilities is an obstacle just in the case of introvert kids.

„We always went to some extra activities, such as handicrafts, painting furniture, bedding, all crafts. We went to music school. I played the piano for five years; I also sang two.... And to play sports, to swim, and... and so we have always been in company with them, and anyway, there was a homeschooling family who had kids about the same age as us and we were with them in such a best friendly status then"(Simon, homeschooled young lady, 2020).

We did not experience socialization problems at most of the homeschooling families, although we also found that probably they have less ties, however these are stronger ones.

"The home-educated kids are in a good relation and so they talk almost every night with each-other, somewhere on Skype or WhatsApp or Meet. Moreover, for example, quite a few people gathered in Budapest this weekend and would spend together in the next weekend as well. There was a time when I thought that if he would have gone to high school, he would have had more friends, maybe, but they have friends who are already 20 years old friends" (Szász, 2015).

The social environment could make it difficult to differ, thus the interviewees experienced a constant need to deal with the public opinion (or the lack of it). Not only the parents had to learn how to support and give a reason to why they homeschool, but the pupils to.

„In the first round, no one generally understood what it is like to study at home. I had never heard of such, now by the time I was done approx. more and more people have come across this concept so to speak. Therefore, the feedback became more and more positive that "wow this is good" and that "he wanted it too, but that it couldn't" and such. As a child it was more annoying that I had to constantly explain what it was and how it could be. Then these questions, always, "then, you don't have friends?" Then everyone saw in his or her eyes that they were poisoning how antisocial I am and so on... but besides anyway... Maybe even in homeschooling it was the most tiring that this had to be explained to people that there is such a way, I can live with it, and I will not be disabled and so on. They really also asked me many times that we had something wrong, that we did not go to normal school... (Simon, young lady, 2020)"

Teaching at home could be difficult not only because it needs commitment, determination, selfdiscipline and many other things but also because many times the parents need to confront the contraopinion of the community, that of officials and sometimes, also that of friends and relatives

"our teacher friends did not receive it at all well, they did not agree with it, because they see their own profession as unnecessary" (Blaga homeschooling parent, 2020).

That is why it is of core importance to be aware of the why's.

To fight back the institutional and social discrimination of the homeschoolers it is important to a have a supporting social network, such as the Association for Homeschooling Romania.

„It is important to have a homeschooling community that can provide theoretical background at some level and can help the family at some level. Families can help each other" (Curcubet homeschooled young men, 2020).

\section{Conclusion}

As we can see above, some of the reason for homeschooling in Szeklerland include parental responsibility, control of children's character formation and direct value transfer, the protection of children from the effects that they are not prepared for. Other reasons are overpassing the generational gap, possibility to give personalized, differentiated education, more focus on children's interest. Furthermore, the interviewees mentioned among the reasons of homeschooling the effective, and real evaluation of performance, competence-based education, real world settings, more results in less time devoted to learning, flexibility, in other words, the educational freedom (Szász, 2015). 
The importance to learn about homeschooling became even more accentuated in the context of pandemics, what was rare and unusual, the homeschooling became part of everyone's daily life.

"A little funny really because so far we have been miracle beetles and now in a few months the whole world has switched to this (Simon, young lady, 2020).

\section{Bibliography}

Journal.

Ray B. D. (2017): A systematic review of the empirical research on selected aspects of homeschooling as a school choice. Journal of School Choice: International Research and Reform. Volume 11, 2017 Issue 4: School Choice: Separating Fact from Fiction. 604-621p. In. https://www.tandfonline.com/doi/full/10.1080/15582159.2017.1395638?src=recsys

Carlson, D. (2009): Homeschooling and bilingual education. A well-kept secret. Encounter: Education for Meaning and Social Justice. 22. 4. sz. 10-13.

Cheng, A. (2014): Does homeschooling or private schooling promote political intolerance? Evidence from a Christian university. Journal of School Choice: International Research and Reform, 8(1), 4968.

Cogan, M. F. (2010): Exploring academic outcomes of homeschooled students. Journal of College Admission, 208, 18-25.

Fields-Smith, C., \& Kisura, M. W. (2013): Resisting the status quo: The narratives of black homeschoolers in Metro-Atlanta and Metro-DC. Peabody Journal of Education, 88(3), 265-283.

Mandel K. M. (2015): Előny a hátrány? Székelyföldi képességvizsga és érettségi eredmények az elmúlt években. (Is disadvantage advantage? Results of ability and final exams in Seclerland.) In. PEDACTA. Vol. 5 No. 2. 23-34. In. http://padi.psiedu.ubbcluj.ro/pedacta/article_5_2_3.pdf

Mandel K. M. (2020) Homeschooling in Secler region, Romania. Acta Educationis Generalis. vol. 10 issue 1. In. https://content.sciendo.com/view/journals/atd/10/1/article-p98.xml

Martin-Chang, S., Gould, O. N., \& Meuse, R. E. (2011): The impact of schooling on academic achievement: Evidence from homeschooled and traditionally schooled students. Canadian Journal of Behavioural Science/Revue Canadienne Des Sciences Du Comportement, 43(3), 195-202.

Montes, G. (2006): Do parental reasons to homeschool vary by grade? Evidence from the national household education survey, 2001. Home School Researcher, 16(4), 11-17.)

NCES (2017): Parent and Family Involvement in Education. Results from the National Household Education Surveys Program of 2016. Institute of Education Sciences. National Center for Education Statistics. In. https://nces.ed.gov/pubs2017/2017102.pdf

Ray, B. D. (2015): African American homeschool parents' motivations for homeschooling and their Black children's academic achievement. Journal of School Choice, 9, 71-96.

Redford, J., Battle, D., \& Bielick, S. (2017): Homeschooling in the United States: 2012. Washington, DC: National Center for Education Statistics, Institute of Education Sciences, U.S. Department of Education. Retrieved August 1, 2017, from. (NCES 2016-096.REV) https://nces.ed.gov/pubsearch/pubsinfo.asp?pubid=2016096rev

Simándi Sz. (2018): Intergenerational Learning - Lifelong Learning. Acta Educationis Generalis, vol 8 issue 2. In. https://content.sciendo.com/view/journals/atd/8/2/article-p63.xml. (Date of access: 2021.06.30)

Thomson, R. A., Jr., \& Jang, S. J. (2016): Homeschool and underage drinking: Is it more protective than public and private schools? Deviant Behavior, 37(3), 281-301. 
Book.

Curcubet G. et alii (2020): Ghid pentru educatia acasa. Teorie si practica. Asociatia Home Schooling Romania. (Guide for home schooling. Theory and practice. Association for Home Schooling Romania.)

Gordon, E. E. \& Gordon E. H. (1990): Centuries of tutoring: A history of alternative education in America and Western Europe. Lanham, MD: University Press of America.

Mandel (2007): The Romanian Higher Education Policy Between 1990-2003. (A román felsőoktatáspolitika 1990-2003 között.) Presa Universitară Clujeană/Kolozsvári Egyetemi Kiadó. 1-248. https://dea.lib.unideb.hu/dea/bitstream/handle/2437/88695/ertekezes.pdf?sequence $=6$

Mandel K. M. (2016): Challenges. Focus on education in Szeklerland. (Kihívások. Középpontban a székelyföldi oktatás kérdései.) Gondolat kiadó. 1- 277 ISBN 978-963-693-731-7

Bottoni S. (2008): Sztálin a székelyeknél. A Magyar Autonóm Tartomány története (1952-1960).

(Stalin at the Szeklers. History of the Hungarian Autonomous Province) Pro-Print Könyvkiadó,

Csíkszereda.

Vygotsky, L. S. (1986): Thought and language. Cambridge, MA MIT Press.

\section{Edited volume.}

Kinga M. Mandel, Papp Z. Attila (2007): Plogging. (Cammogás) Soros Education Center, Csíkszereda.

Web sources.

Szász A. (2015): Introduction to homeschooling. (Bevezetés az otthonoktatásba.) In. https://www.youtube.com/watch?v=4auTBUsLgBY

Szász A. (2015): Notes on homeschooling. (Jegyzetek az otthonoktatásról) AHSR former homepage. In. https://docplayer.hu/5039498-A-a-tanugyi-kaderek-oktathassanak-a-diak-otthonaban-is-mintmagantanarok.html

Curcubet D. (2015): Going to university? How? (Egyetemre? Hogyan?) In. https://www.youtube.com/watch?v=WW5-VcnAV3c

Curcubet G. (2015): Obstacles and difficulties in home education. (Akadályok és nehézségek az otthonoktatásban.) In. https://www.youtube.com/watch?v=vlZE4aDHUkw

Ken Robinson (2006): Do schools kill creativity? https://www.ted.com/talks/sir_ken_robinson_do_ $\underline{\text { schools_kill_creativity?language }=\text { hu }}$

Eggendorfer N. C. (2016): Magyar otthonoktató családok vizsgálata tematikus blogok elemzésével. Szakdolgozat. (Investigation of Hungarian homeschooling families by analyzing thematic blogs.

Thesis). https://mek.oszk.hu/16800/16886/16886.pdf.

Ray, B. D. (2019): Facts on homeschooling. http://www.nheri.org/research/research-facts-onhomeschooling.html

Romanian Homeschooling Association (2019): Homeschooling. (Otthonoktatás). https://homeschool ing.ro/otthonoktatas/

Sinek S. (2009): How great leaders inspire action. Ted talk. https://www.ted.com/talks/simon_sinek_ how great leaders inspire action 
Smith, L. W. (2000): Stakeholder analysis: a pivotal practice of successful projects. Paper presented at Project Management Institute Annual Seminars \& Symposium, Houston, TX. Newtown Square, PA: Project Management Institute. In. https://www.pmi.org/learning/library/stakeholder-analysis-pivotalpractice-projects-8905

Taylor-Hugh, D. (2010): Are All Homeschooling Methods Created Equal? http://files.eric.ed.gov/full text/ED510702.pdf

Miller T. (2014): How Is Unschooling Different From Homeschooling? https://www.noodle.com/ articles/how-is-unschooling-different-from-homeschooling

\section{Author}

Kinga Magdolna Mandel, ELTE PPK Felnőttképzés-kutatási és Tudásmenedzsment Intézet, Budapest (Hungary). E-mail: mandel.kinga@ppk.elte.hu

\section{Acknowledgement}

Our research was supported by the Hungarian Government through the Bethlen Gábor Alapkezelö (BGA) Zrt. and supported by the Association Home Schooling Romania (AHSR). Special thanks to the interviewed homeschooling parents and their youngsters and for Nikolett Berecz, student at ELTE PPK FTI for contributing to the data recording. 